\title{
Modelling hydrochemical and ecological trends in acid sensitive surface waters in the Scottish Highlands
}

\author{
Rachel C. HELLIWELL* and Martin KERNAN ${ }^{1)}$ \\ Macaulay Institute, Craigiebuckler, Aberdeen AB15 8QH, UK \\ ${ }^{1)}$ Environmental Change Research Centre, University College London, London WC1H OAP, UK \\ *e-mail corresponding author: r.helliwell@macaulay.ac.uk
}

\begin{abstract}
The dynamic model MAGIC is used to predict the future response of surface waters to reductions in $S$ deposition as stipulated by the recently agreed emission protocol (the 1999 Gothenburg Protocol). MAGIC was calibrated to 30 sites in the Scottish mountains with the best available soil and deposition data derived from large scale spatial datasets, and surface water chemistry from a regional loch survey conducted in October 2000. A comparison of input parameters and model responses are made at Lochnagar, a site for which detailed, high resolution spatial/temporal data exist. The model is capable of reproducing observed trends in non-marine $\mathrm{SO}_{4}^{2-}$, however simulated $\mathrm{NO}_{3}^{-}$from 1990 to 2000 is lower than the observed trends at Lochnagar due to possible hydrological controls and in-lake processes, rather than terrestrial processes. The Scottish Highlands are remote from emission sources and consequently peak deposition inputs of $S$ in the 1980s are relatively low (33 $\mathrm{kg} \mathrm{S} \mathrm{hal} \mathrm{g}^{-1}$ ) compared to other regions in Europe. Nonetheless the amount of deposition appears sufficient to cause environmental damage in this acid sensitive region. During the 1980s, simulated Acid Neutralising Capacity (ANC) of $13 \%$ of the modelled lakes was $<20 \mu e q l^{-1}$, a chemical condition that potentially can cause damage to freshwater ecology. Regional and site simulations captured the recovery to 2000 in response to the existing emission reductions. Predictions to 2016 indicates the potential for biological recovery and a return to 'good status' as required by the EU Water Framework Directive, although the hydrochemistry of some sites remain some way from simulated pre-acidification conditions.
\end{abstract}

Key words: acid deposition, recovery, ecology, scale, Scotland

\section{INTRODUCTION}

The physical nature of the Scottish Highlands and their geographical position has created a montane environment that can be considered unique in European terms. The Scottish Highlands lie between the northern extremity of the alpine environments and the southern extremity of the arctic environments (Johnson \& Thompson 2002). It is estimated that the area of land above $500 \mathrm{~m}$ form some $11 \%$ of the total landmass of Scotland. At high altitudes the environment is associated with low temperatures, long periods of snow and ice cover, base poor soils and sparse vegetation cover. Due to their remote location, local human activity is usually very low or absent. Potentially pristine by their location, high altitude mountain lochs (lakes) are very sensitive to subtle changes in climate and anthropogenic deposition (Helliwell et al. 2002).

Acidification of surface waters has been widespread across the uplands of the UK from the mid 19th century. The main cause of acidification is deposition of anthropogenic sulphur $(\mathrm{S})$, although nitrogen $(\mathrm{N})$ compounds contribute significantly in some areas (NEGTAP 2001). Evidence for surface water acidification can be obtained from $\mathrm{pH}$ reconstructions based on diatoms in lake sediment cores and this provides the key evidence linking historical emission of atmospheric pollutants to the acidification process (Battarbee et al. 1990; Jones et al. 1993). Recognition of the severity of surface water acidification resulted in International agreements leading to reductions in emissions of acidifying $\mathrm{S}$ and $\mathrm{N}$ compounds (UN-ECE 1999). The most recent UN-ECE agreement, the Multi-Pollutant Multi-Effect Protocol (Gothenburg Protocol), was signed in 1999 with the aim of abating emissions of sulphur, nitrogen oxides, ammonia, and volatile organic compounds. When fully implemented in 2016 this protocol aims to reduce S emissions across Europe by at least $63 \%$, NOx by $41 \%$ and $\mathrm{NH}_{3}$ by $17 \%$ relative to 1990 levels, these reduction are already substantially reduced from the peak levels of the late 1970 s and 1980 s as a result of the earlier agreements (Jenkins et al. 2003).

The implementation of such pollution control strategies is costly, and it is assumed that these strategies will contribute to substantial benefits in environmental quality, both in terms of improvements in surface water chemistry/ecology and in human health etc. One important expected benefit is the recovery of acidified, biologically impoverished, freshwater systems. International efforts to further protect and manage acid sensitive ecosystems have led to the implementation of the EC Water Framework Directive (Directive 2000/60/EC). This Directive states that 'good' ecological status relative to a 'reference condition' must be achieved by 2016 (Chave 2001). Although conditions 


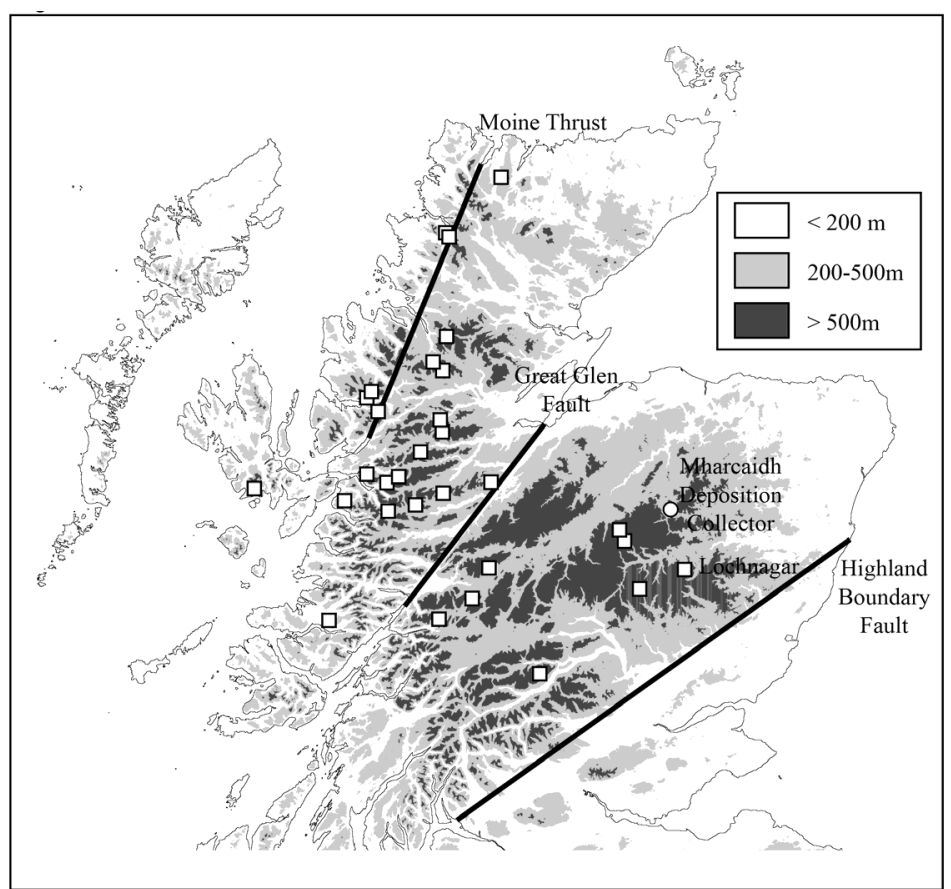

Fig. 1. Altitudinal map showing the location of 30 sites within the Scottish Highlands.

are yet to be defined, it is assumed that 'reference condition' relates to an expected chemical and ecological status prior to the onset of industrialisation and soil/water acidification in the case of acidification pressure, and a key indicator of good ecological status is the presence of a viable brown trout population. The relationship between water chemistry and the survival of brown trout was investigated by Henriksen et al. (1989) in his analysis of data from the Norwegian 1000-lake survey. In a later study, Lien et al. (1996) linked the probability of occurrence of trout populations to the surface water Acid Neutralising Capacity (ANC). The nature and extent of future regional recovery from acidification is, however, dependent upon the historical pattern of deposition, regional ecosystem characteristics, and the role of confounding factors, which may delay the onset of recovery, or the magnitude of response (Ferrier et al. 2003).

The purpose of this study was to evaluate the current biogeochemical status of Scottish mountain lochs in relation to current deposition inputs, catchment characteristics and processes, and model the response of these acid sensitive sites to future changes in deposition. A comparison is made between modelled responses at Lochnagar, calibrated with high-resolution data at an intensively monitored site and spot samples taken as part of a regional study, calibrated with low-resolution data.

\section{METHODOLOGY}

The sites selected in this paper form part of a panEuropean survey of mountain 'Lakes Districts'. The EU project, EMERGE (European Mountain lake Ecosys- tems: Regionalisation, diaGnostic \& socio-economic Evaluation), includes 13 'Lake Districts' covering an area from the north of Finland, to Bulgaria in the east, the Pyrenees to the southwest and Greenland, out with Europe, to the northwest (to represent base-line conditions in a potentially pristine environment). In the context of this paper 'Lake District' is defined as the Scottish Highlands.

The main objective of this study was to identify the ecological and hydrochemical impacts of atmospheric pollution on mountain ecosystems, therefore sites were selected with a no known history of site disturbance or intensive land management practices. To avoid catchment-based anthropological influences, the survey was confined to sites above a theoretical tree-line. The theoretical tree-line in upland Scotland varies with latitude and longitude. Regional tree-lines have been suggested for the Grampians (Donner 1962; Huntley 1981), Cairngorm (Pears 1968) and north-west Highlands and these were used to guide the site sampling strategy. Using a GIS (Geographic Information System) and the Ordnance Survey 1:50,000 digital map, all lochs above the altitude thresholds across the three regions were identified (Grampians, $700 \mathrm{~m}$; Cairngorms, $750 \mathrm{~m}$ and NW Highlands, $500 \mathrm{~m}$ ). Other selection criteria included a lower loch area limit of $0.5 \mathrm{ha}$, the requirement for all major geological units to be represented, and the geographical extent of the Scottish Highlands to be covered (Fig. 1). A subset of 30 headwater lochs were selected for this analysis from a total of 399 and sampled during September-October, 2000. The survey in Scotland was limited to a subset 30 lochs that were selected to represent the altitudinal range above the tree-line in the 
Tab. 1. Characteristics of the study sites in the Scottish Highlands. ${ }^{*}$ GneSan: Gneiss with schist and sandstones; L:C: Loch:Catchment; ND: No data; Ppt: Precipitation; BP: Blanket Peat; R: Ranker; PP: Peaty podzol: PG: Peaty gley; SA: Subalpine soil; A: Alpine soil.

\begin{tabular}{|c|c|c|c|c|c|c|c|c|}
\hline Lake Code & Name & Grid reference & Geology & $\begin{array}{l}\text { Soil type } \\
(\% \text { area })\end{array}$ & $\begin{array}{c}\mathrm{Ppt} \\
\left(\mathrm{mm} \mathrm{y}^{-1}\right)\end{array}$ & $\begin{array}{c}\text { Elevation } \\
\text { (m a.s.1.) }\end{array}$ & $\begin{array}{l}\text { Site area } \\
\text { (ha) }\end{array}$ & $\mathrm{L}: \mathrm{C}$ \\
\hline SC0002 & Loch Coir A Ghrunnda & NG 452202 & Gneiss & Rock and scree 100 & 2.60 & 698 & 31 & 0.09 \\
\hline SC0010 & Lochan Bac An Lochain & NM 764650 & Gneiss & SA 100 & 2.33 & 577 & 16 & 0.11 \\
\hline SC0029 & Un-Named & NG 829149 & Gneiss & BP 100 & 2.09 & 715 & 20 & 0.12 \\
\hline SC0067 & Loch Coire na Caime & NG 922582 & Gneiss & SA 100 & 2.16 & 700 & 116 & 0.03 \\
\hline SC0068 & Loch Bhuic Moir & NG 922261 & Gneiss & BP 100 & 2.21 & 700 & 27 & 0.13 \\
\hline SC0076 & Loch Coire Mhic Fhearchair & NG 942609 & *GneSan & SA 100 & 2.34 & 592 & 171 & 0.06 \\
\hline SC0084 & Un-Named & NG 969525 & *GneSan & SA 100 & 2.52 & 665 & 50 & 0.19 \\
\hline SC0101 & Loch a' Chleirich & NH 007226 & Gneiss & SA 100 & 2.61 & 774 & 18 & 0.08 \\
\hline SC0108 & Un-Named & NH 012106 & Gneiss & SA 100 & 3.02 & 665 & 63 & 0.03 \\
\hline $\mathrm{SC} 0124$ & Loch an Fhraoich Choire & NH 056250 & Gneiss & PP 14, SA 85, A 1 & 2.34 & 757 & 43 & 0.10 \\
\hline SC0140 & Gorm Lochan & NH 125133 & Gneiss & SA 100 & 2.28 & 817 & 24 & 0.07 \\
\hline SC0153 & Loch Beag & NH 146355 & Gneiss & PP 9, SA 91 & 2.10 & 658 & 70 & 0.03 \\
\hline SC0165 & Loch a' Mhadaidh & NH 199732 & Gneiss & SA 89, BP 11 & 1.91 & 567 & 239 & 0.13 \\
\hline SC0172 & Un-Named & NN 225654 & Gneiss & SA 100 & 2.75 & 736 & 50 & 0.19 \\
\hline SC0180 & Loch Toll Lochan & NH 230489 & Slate & SA 100 & 1.75 & 518 & 98 & 0.08 \\
\hline SC0189 & Loch Du Fhuar Thiull Mhoir & NH 239440 & Gneiss & SA 100 & 1.79 & 768 & 54 & 0.10 \\
\hline SC0190 & Loch Gorm & NH 240696 & Gneiss & SA 100 & 1.71 & 538 & 142 & 0.15 \\
\hline SC0191 & Loch Carn a' Chaochain & NH 241181 & Slate & BP 100 & 1.58 & 657 & 10 & 0.24 \\
\hline SC0197 & Loch a' Choire Dhairg & NC 252272 & Gneiss & SA 57, PG 43 & 2.19 & 525 & 43 & 0.10 \\
\hline SC0204 & Lochan a' Chnapaich & NH 257838 & Gneiss & A 100 & 2.06 & 648 & 93 & 0.06 \\
\hline SC0211 & Loch Bealach na H-Uidhe & NC 264256 & Gneiss & SA 100 & 2.22 & 534 & 49 & 0.06 \\
\hline $\mathrm{SC} 0271$ & Lochan Coire nan Lochain & NN 363743 & Gneiss & PP 30, A $30, \mathrm{R} 40$ & 2.00 & 738 & 160 & 0.03 \\
\hline SC0330 & Loch Coire Choille Rais & NN 433867 & Gneiss & A $24, \mathrm{R} 76$ & 1.62 & 807 & 54 & 0.14 \\
\hline SC0335 & Un-Named & NH 444228 & *GneSan & P 100 & 1.08 & 538 & 27 & 0.07 \\
\hline SC0349 & Un-Named & NC 485505 & Gneiss & PG 8 , SA 92 & 1.55 & 536 & 60 & 0.06 \\
\hline SC0366 & Lochan nan Cat & NN 645426 & Gneiss & BP 11, SA 18, A 21, R 49 & 1.89 & 717 & 216 & 0.06 \\
\hline SC0379 & Un-Named & NH 981029 & Granite & R 100 & 1.64 & 917 & 72 & 0.01 \\
\hline SC0382 & Lochan Uaine & NO 001981 & Granite & $\mathrm{R} 100$ & 1.38 & 956 & 38 & 0.10 \\
\hline SC0386 & Loch nan Eun & NO 064781 & ND & BP 55, R 45 & 1.20 & 783 & 75 & 0.19 \\
\hline SC0399 & Lochnagar & NO 252860 & Granite & $\mathrm{R} 100$ & 1.13 & 787 & 104 & 0.10 \\
\hline
\end{tabular}

Grampian and Cairngorm Mountains, and the northwest Highlands. Logistical constraints also limited the number of sites selected for this study. A water sample was taken at the outflow of each site and analysed for a suite of chemical determinands using standard methods (Harriman et al. 1990).

\subsection{Environmental characterisation}

\subsubsection{Scottish Highlands}

The Scottish Highlands comprise 30 high altitude sites spanning three physiographic regions, each bounded by a fault line (Fig. 1). The area to the southeast of the Great Glen Fault is underlain by pre-Cambrian metamorphic rocks into which a number of granitic plutons have intruded forming the high plateau of the Cairngorm mountains. To the north of the Great Glen Fault, the majority of sites are located on the oldest geological formations of gneiss and schists from the pre-Cambrian era. The Northern Highlands is an extensive area that includes most of the land to the north of the Great Glen Fault. Five sites in the Northern Highlands are located in a small area west of the Moine Thrust, where Lewisian rocks are dominant (Langan \& Soulsby 2001). To the south of this area the topography is rugged and steep rocky slopes with crags and scree are widespread. To the east of the Moine Thrust, the majority of the land is less rugged, comprising a dissected plateau, highest in the south and sloping northwards to the coast. This area is underlain by Moinain rocks, which are predominantly gneiss and granulites.

Throughout northern Scotland, at high altitudes, semi-natural vegetation of heather moorland and blanket bog dominate. Most montane soils are poorly developed and naturally acidic which has resulted in the extensive development of alpine habitats. Alpine heaths, for example, carpet the unstable wind-blasted gravel fields of the central Cairngorms. The soils are dominated by thin alpine and sub-alpine soil with some rankers (Tab. 1). In areas of gentle relief, these mineral soil assemblages can be secondary to the accumulation of peat. The high altitude and remoteness of this Scottish Highlands means that active land-management has been restricted or is absent. Many of the sites lie above the limit of sheep grazing, however, red deer (Cervus elaphus) browse across most sites. Mean annual precipitation ranges from $1.1 \mathrm{~m} \mathrm{y}^{-1}$ in the east to $>3.0 \mathrm{~m} \mathrm{y}^{-1}$ in the west (Tab. 1). Winter snowfall is substantial at high elevation, and can contribute $\sim 30 \%$ of mean annual precipitation in some areas (Dunn et al. 2001). The magnitude of acid deposition in remote Scottish mountains is minor relative to other areas of the UK with deposi- 
tion inputs of c. $14 \mathrm{~kg} \mathrm{ha}^{-1} \mathrm{y}^{-1} \mathrm{~S}$ and $c a 8 \mathrm{~kg} \mathrm{ha}^{-1} \mathrm{y}^{-1} \mathrm{~N}$ (Monteith \& Evans 2000; Helliwell et al. 2003).
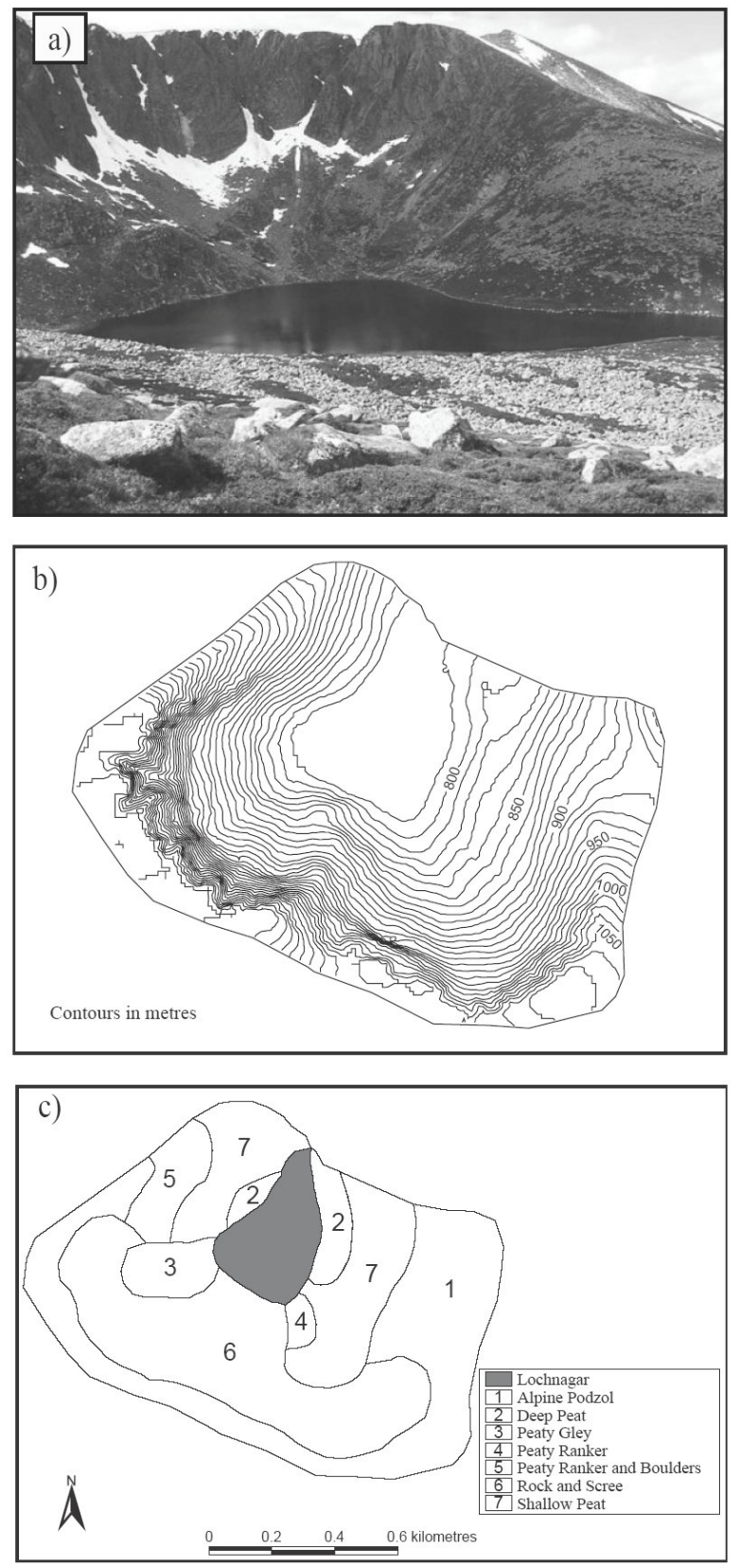

Fig. 2. a) Photograph of the Lochnagar catchment, b) topographic map derived from a Digital Elevation Model, and c) soil map $(1: 10,000)$.

\subsubsection{Site description - Lochnagar}

The Lochnagar catchment (NO 252 859) is the most easterly site in the Scottish Highlands (Fig. 2a). The catchment area (104 ha) is average, compared to other sites in this study with an altitudinal range of 787-1150 m (Fig. 2b). The complex geomorphology of Lochnagar has resulted in heterogeneous distribution of soil types and vegetation (Fig. 2c). The vegetation is dominated by stunted Calluna vulgaris, Empetrium, Vaccinium myrtillus and Lycopodium and some Sphagnum sp. near the loch edge (Fig. 2c). Lochnagar is characterised by alpine soils and localised areas of peat, which are severely eroded along the north-eastern shore of the loch (Fig. 2c). A particularly prominent feature of this catchment is the steep north-facing corrie that comprises $c a 30 \%$ of the catchment area. Geologically the catchment is composed of biotite granite (Jenkins et al. 2001). Compared to other sites in the Scottish Highlands, Lochnagar is particularly sensitive to acidification in relation to the soil/geology and geomorphic characteristic of the site; in addition this site receives $19 \mathrm{~kg} \mathrm{~N} \mathrm{ha}^{-1} \mathrm{y}^{-1}$ and $21 \mathrm{~kg} \mathrm{~S} \mathrm{ha}^{-1} \mathrm{y}^{-1}$ (based on mean data from 19982000).

\subsection{Parameterisation of the MAGIC model}

\subsubsection{The MAGIC model}

MAGIC is a lumped-parameter model, developed to predict the long-term effects of acidic deposition on soil and surface water chemistry (Cosby et al. 1985a, b, 2001). The model simulates soil solution and surface water chemistry to predict average concentrations of the major ions. MAGIC calculates, at annual time steps, the concentrations of major ions by simultaneous reactions involving sulphate adsorption, cation exchange, dissolution-precipitation-speciation of aluminium and dissolution-speciation of inorganic and organic carbon. A set of mass balance equations in which fluxes of major ions to and from the soil and surface water are assumed to be governed by atmospheric inputs, mineral weathering, net uptake by biomass and loss in runoff. MAGIC produces long-term reconstructions and predictions of soil and surface water chemistry in response to scenarios of acid deposition.

In any catchment scale model application, complex soil physico-chemical processes that lead to loss of soil base status and the acidification of surface waters are simplified so that models can be applied at large spatial scales. MAGIC uses a 'lumped' parameter approach to; (i) aggregate the complex biological and chemical processes active at the catchment scale into a few readily described processes; and (ii) lump catchment characteristics to represent the spatial heterogeneity of soil properties throughout a catchment.

In this model application, there are no process-based mechanisms for $\mathrm{N}$ retention in soil, and first order uptake coefficients were calibrated to represent catchment immobilisation such that input matched output at present day (Cosby et al. 1985a, b). These uptake coefficients were then assumed to remain constant into the future. The MAGIC calibration procedure followed is documented by Jenkins et al. (1998) and Evans et al. 



Fig. 3. a) Historical and future deposition of non-marine $\mathrm{SO}_{4}{ }^{2-}, \mathrm{NO}_{3}{ }^{-}$and $\mathrm{NH}_{4}{ }^{+}$relative to the calibration year 2000 used in MAGIC applications for the Scottish Highlands (from Mylona (1996) and Simpson et al. (1997) as modified by Posch et al. (2002)), b) Total deposition of non marine $\mathrm{SO}_{4}{ }^{2-}$ from the Mharcaidh deposition collector (NH 876052) measured as part of the UK Acid Deposition Monitoring Programme and modelled by EMEP (Posch et al. 2002) relative to values for 2000.

(2001). The calibrations are performed on simulations run for 150 years to 2000 .

\subsubsection{Deposition sequences}

Historical and future changes in deposition rates of non-marine sulphate $\left(\mathrm{xSO}_{4}\right)$, nitrate $\left(\mathrm{NO}_{3}{ }^{-}\right)$, and ammonium $\left(\mathrm{NH}_{4}^{+}\right)$are represented in MAGIC by scale factors, linked to present day deposition (Fig. 3a). Historical $\mathrm{SO}_{4}{ }^{2-}$ deposition (EMEP) is scaled to the estimated deposition history of the Scottish Highlands as calculated by Mylona, (1996) and modified by Posch et al. (2002). Similarly the deposition of $\mathrm{NO}_{3}{ }^{-}$and $\mathrm{NH}_{4}{ }^{+}$is scaled to the estimated deposition history for Europe given by Simpson et al. (1997) and modified by Posch et al. (2002) (Fig. 3a). The future deposition scenario based on the Gothenburg Protocol is estimated (Posch et al. 2002). Other ions in deposition are assumed to remain constant throughout the simulation

It is important that modelled deposition sequences agree with observed data since deposition is one of the main factors driving environmental change in upland freshwaters. The longest deposition record in the Scottish Highlands (Mharcaidh deposition collector $\mathrm{NH}$ 876052) is compared with the EMEP modelled deposition data (Fig. 3b). Generally the timing and magnitude of change between modelled and observed deposition data are good (Fig. 3b), however, there is a minor discrepancy between the sequences in the early record (1986 and 1994). Since there are few reliable, longterm, deposition records in the Scottish mountains, the deviation between modelled and observed deposition sequences is difficult to quantify. Although Mharcaidh gauge is situated at relatively low altitude $(\sim 200 \mathrm{~m}$ a.s.l), the general deposition trend is reproduced by the modelled EMEP data, but as expected, year-to-year variability in deposition and meteorological conditions is considerable.

\subsubsection{Data sources}

In large-scale studies, it is important that each calibration in a region (Scottish Highlands) conforms to a standard methodology and utilises consistent data, in this regard, all datasets were processed using standard protocols. Input data required by MAGIC includes annual rainfall and runoff volumes, deposition chemistry, and catchment aggregated soil physico-chemical parameters including depth, bulk density and cation exchange capacity. The MAGIC model is calibrated to measured 'target variables'; surface water concentrations of acid anions $\mathrm{SO}_{4}{ }^{2-}$, chloride $\left(\mathrm{Cl}^{-}\right), \mathrm{NO}_{3}^{-}, \mathrm{NH}_{4}^{+}$and base cations calcium $\left(\mathrm{Ca}^{2+}\right)$, magnesium $\left(\mathrm{Mg}^{2+}\right)$, sodium $\left(\mathrm{Na}^{+}\right)$, and potassium $\left(\mathrm{K}^{+}\right)$, and soil exchangeable fractions of the same base cations.

Mean wet deposition data for the period 1995-97 was used in the Scottish Highlands model application; this data was derived from the most suitable UK Acid Deposition Monitoring Network (ADMN) sites. These data were interpolated to provide estimates of wet deposition on a $20-\mathrm{km}$ grid. These values were modified, using the mean altitude of each grid cell, to account for the variation of rainfall and ion concentration in rainfall with altitude due to orographic enhancement mechanisms (Fowler et al. 1988). Rainfall volumes were calculated using a similar method from a $20 \times 20 \mathrm{~km}$ grid. For the site application at Lochnagar, rainfall and deposition data is derived from a collector in the ADMN, the River Mharcaidh (NH 876 052).

Soil physico-chemical data were aggregated using a catchment-based vertical and spatial weighting technique (Helliwell et al. 1998). From the 1:250,000 soil map of Scotland, a number of different soil types were identified from the 30 sites comprising the Scottish Highlands. Data from the nearest appropriate soil profile in the Scottish Soils Database (Macaulay Institute) was extracted and weighted for the calibration. Due to the low sampling resolution of soils in the remote Scottish uplands there are few instances where soil data is available from within the catchment boundary of the 30 sites. In contrast, for the site application at Lochnagar, the spatial distribution of different soil types was derived from a detailed 1:10,000 soil map. Soils were sampled from within the catchment boundary and spatially and 
Tab. 2. Surface water chemistry from 30 sites in the Scottish Highlands (sampled 2000) and mean chemistry from Lochnagar (1988-1993). Cond (Conductivity), DOC (Dissolved Organic Carbon), $\mathrm{xSO}_{4}$ non marine $\mathrm{SO}_{4}{ }^{2-}$, ANC (Acid Neutralising Capacity), Al-NL (Non labile aluminium), Al-L (Labile aluminium).

\begin{tabular}{|c|c|c|c|c|c|c|c|c|c|c|c|c|c|}
\hline & $\mathrm{pH}$ & $\begin{array}{c}\text { Cond } \\
\mu \mathrm{S} \mathrm{cm}^{-1}\end{array}$ & $\begin{array}{c}\mathrm{Ca}^{2+} \\
\mu \text { eq } 1^{-1}\end{array}$ & $\begin{array}{l}\mathrm{Mg}^{2+} \\
\mu \text { eq } \mathrm{l}^{-1}\end{array}$ & $\begin{array}{c}\mathrm{Na}^{+} \\
\mu \text { eq } 1^{-1}\end{array}$ & $\begin{array}{l}\mathrm{xSO}_{4}{ }^{2-} \\
\mu \text { eq } 1^{-1}\end{array}$ & $\begin{array}{c}\mathrm{SO}_{4}{ }^{2-} \\
\mu \text { eq } \mathrm{l}^{-1}\end{array}$ & $\begin{array}{l}\mathrm{NO}_{3}^{-} \\
\mu \text { eq } 1^{-1}\end{array}$ & $\begin{array}{c}\mathrm{Cl}^{-} \\
\mu \mathrm{eq} \mathrm{l}^{-1}\end{array}$ & $\begin{array}{c}\text { ANC } \\
\mu \text { eq } 1^{-1}\end{array}$ & $\begin{array}{c}\text { Al-NL } \\
\mu \mathrm{g} \mathrm{l}^{-1}\end{array}$ & $\begin{array}{l}\text { Al-L } \\
\mu g ~^{-1}\end{array}$ & $\begin{array}{l}\mathrm{DOC} \\
\mathrm{mg} \mathrm{l}^{-1}\end{array}$ \\
\hline \multicolumn{14}{|l|}{ Scottish Highlands } \\
\hline Average & 6.31 & 27 & 65 & 45 & 140 & 17 & 32 & 2 & 144 & 77 & 11 & 2 & 2.8 \\
\hline Median & 6.19 & 28 & 51 & 47 & 136 & 15 & 28 & 2 & 131 & 68 & 9 & 1 & 2.4 \\
\hline Minimum & 5.42 & 11 & 21 & 15 & 50 & 4 & 18 & 0 & 47 & 16 & 0 & 0 & 0.7 \\
\hline Maximum & 7.14 & 44 & 250 & 76 & 250 & 41 & 53 & 13 & 274 & 273 & 41 & 8 & 9.2 \\
\hline $\mathrm{P} 10$ & 5.86 & 18 & 32 & 29 & 72 & 5 & 23 & 0 & 68 & 29 & 0 & 0 & 0.9 \\
\hline P90 & 6.81 & 37 & 102 & 61 & 214 & 33 & 46 & 4 & 233 & 121 & 25 & 4 & 5.7 \\
\hline Lochnagar (Region) & 5.42 & 18 & 32 & 32 & 77 & 35 & 43 & 13 & 73 & 16 & 12 & 7 & 1.6 \\
\hline Lochnagar (Site) & 5.40 & 21 & 29 & 32 & 89 & 51 & 60 & 11 & 82 & -4 & No Data $\mathrm{N}$ & No Data & 0.9 \\
\hline
\end{tabular}

vertically weighted (Helliwell et al. 1998). Since it is desirable to parameterise MAGIC with catchment based high-resolution data, a comparison between a MAGIC application with high (site) and low (regional) resolution data (Tab. 3) is performed at Lochnagar. Surface water data from the survey conducted in 2000 were used to define the target variables in the regional calibration. The site calibration was conducted with mean data from 1988-1993 because the declining trend in $\mathrm{SO}_{4}$ precludes the use of mean data from the entire monitored period (1988-2001, Jenkins et al. 2001).

Records of diatom flora taken from loch sediment cores at Lochnagar provide evidence of a longer term record of the timing, rate and magnitude of biological and chemical change at this acid sensitive site (Juggins et al. 1996). These records also provide a means to evaluate the historical $\mathrm{pH}$ trends in MAGIC (Jenkins et al. 1990). The core used to compare the MAGIC hindcast simulation was taken in 1991, using general procedures described by Monteith \& Evans (1998).

\section{RESULTS}

\subsection{Current status of surface water chemistry in the Scottish Highlands}

Summary statistics for water chemistry determinands are presented in table 2. Generally, these lochs are of a dilute nature, with relatively low median conductivity $\left(28 \mu \mathrm{S} \mathrm{cm}^{-1}\right), \mathrm{Na}^{+}\left(136 \mu \mathrm{eq} \mathrm{l} \mathrm{l}^{-1}\right)$ and $\mathrm{Cl}^{-}(131$ $\mu$ eq $1^{-1}$ ) concentrations. The lowest ANC concentrations $\left(<50 \mu\right.$ eq $\left.1^{-1}\right)$ correspond to the lochs with $\mathrm{pH}$ below 6.0. At these low ANC sites pronounced effects of acidification on micro-organisms, zooplankton, benthos and fish often occur (Raddum \& Skjelkvale 2001). Median nitrate concentrations are very low $\left(2 \mu \mathrm{eq} \mathrm{l}^{-1}\right)$, the highest $\mathrm{NO}_{3}{ }^{-}$concentrations $\left(13 \mu \mathrm{eq} \mathrm{l^{-1 }}\right)$ were observed both at Lochnagar, the most easterly site, and Loch Coir A Ghrunnda, the most westerly site. Ammonium concentrations are negligible at most sites. Low values for $\mathrm{DOC}$ and $\mathrm{NO}_{3}^{-}$, suggest that these systems are nutrient poor with minimal organic input from catchment sources. A comparison of surface water target chemistry at Lochnagar, as used in the site and regional MAGIC application, is shown in table 2 .

Tab. 3. Values of fixed and calibrated (bold) model parameters at Lochnagar for the site and regional (Scottish Highlands) application.

\begin{tabular}{|c|c|c|}
\hline & Site & Regional \\
\hline Precipitation (m) & 0.80 & 1.13 \\
\hline Runoff (m) & 0.72 & 1.01 \\
\hline \multicolumn{3}{|l|}{ Soil parameters } \\
\hline Depth (m) & 1.1 & 1.0 \\
\hline Bulk Density $\left(\mathrm{kg} \mathrm{m}^{-3}\right)$ & 1002 & 1154 \\
\hline $\operatorname{CEC}\left(\right.$ meq $\left.\mathrm{m}^{-3}\right)$ & 127 & 116 \\
\hline $\mathrm{SO}_{4}^{2-}$ Maximum Capacity $\left(\mathrm{meq} \mathrm{kg}{ }^{-1}\right)$ & 0.01 & 0.01 \\
\hline $\mathrm{SO}_{4}{ }^{2-}$ Half Saturation $\left(\mathrm{meq} \mathrm{m} \mathrm{m}^{-3}\right)$ & 100 & 100 \\
\hline $\mathrm{KAlOH}_{3}(\log )$ & 8.99 & 9.03 \\
\hline $\mathrm{pCO}_{2}(\mathrm{~atm})$ & 0.66 & 0.66 \\
\hline $\operatorname{DOC}\left(\mathrm{mmol} \mathrm{m}^{-2}\right)$ & 50 & 100 \\
\hline \multicolumn{3}{|l|}{ Exchangable Base Cations (\%) } \\
\hline $\mathrm{Ca}^{2+}$ & 1.63 & 1.15 \\
\hline $\mathbf{M g}^{2+}$ & 0.80 & 0.83 \\
\hline $\mathrm{Na}^{+}$ & 0.29 & 0.26 \\
\hline $\mathbf{K}^{+}$ & 0.64 & 0.50 \\
\hline Base Saturation & 3.36 & 2.74 \\
\hline \multicolumn{3}{|l|}{ Surface Water Parameters } \\
\hline Retention time (y) & 0.64 & 0.64 \\
\hline $\mathrm{KAlOH}_{3}(\log )$ & 10.3 & 10.3 \\
\hline $\mathrm{pCO}_{2}(\mathrm{~atm})$ & 0.134 & 0.12 \\
\hline $\operatorname{DOC}\left(\mathrm{mmol} \mathrm{m}^{-3}\right)$ & 4 & 10 \\
\hline
\end{tabular}

\subsection{Trends in surface water chemistry at Lochnagar}

In contrast to the single water sample taken from sites in the Scottish Highlands, fortnightly samples were taken from the outflow of Lochnagar between 1988 and 2001 allowing trend analysis and model validation (Fig. 4). Between 1988 and 1992 a pH increase was observed in response to the decline in $\mathrm{NO}_{3}{ }^{-}$and $\mathrm{xSO}_{4}$, but this trend was not statistically significant. A change in this trend was detected in 1993. Trend analyses performed on the entire dataset from 1988-2000 (Evans \& Monteith 2002), show a significant decline in $\mathrm{xSO}_{4}(-0.94$ $\mu$ eq $1^{-1} \mathrm{y}^{-1}$, significant at the 0.01 level), but no significant long-term trend in $\mathrm{pH}$. This trend may result from 
a)

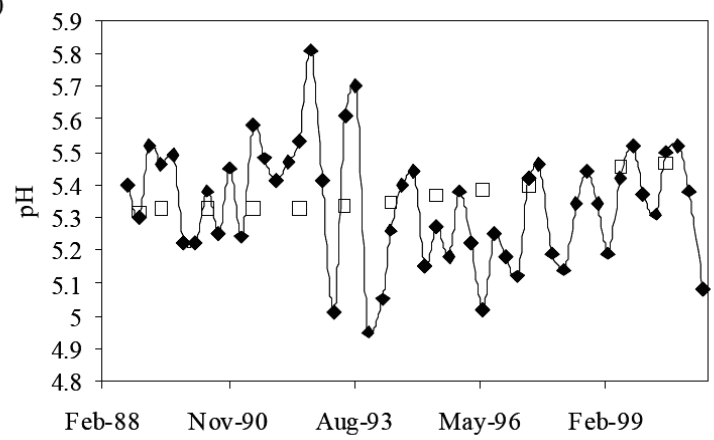

b)

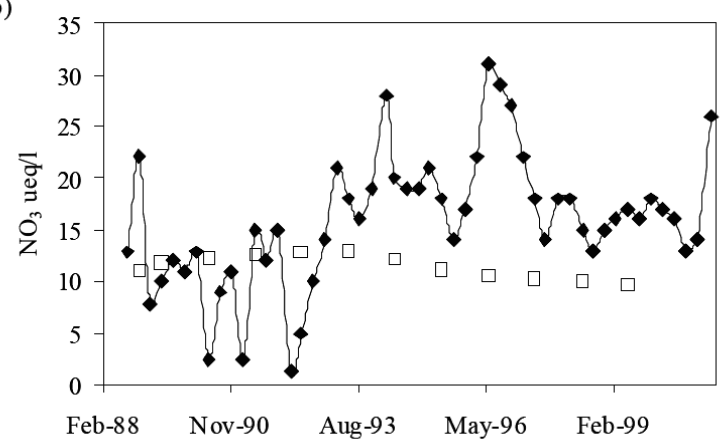

c)

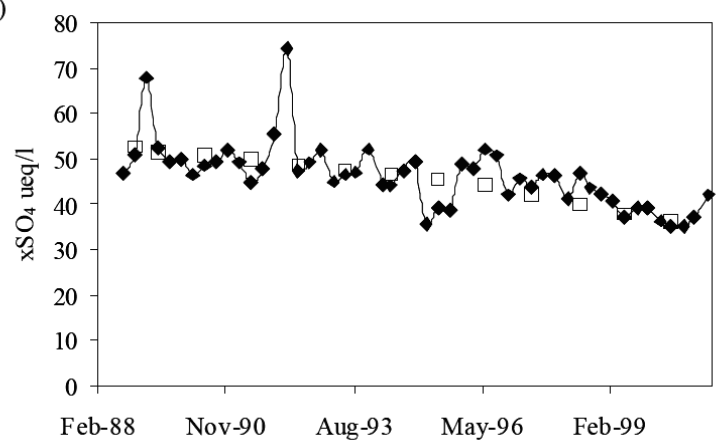

d)



Fig. 4. Observed and modelled trends in surface water chemistry a) $\mathrm{pH}, \mathbf{b}) \mathrm{NO}_{3}^{-}$, c) $\mathrm{xSO}_{4}$ and d) $\mathrm{ANC}$ at Lochnagar 1988 to 2001(Observed data from the UKAWMN).

the enhanced production of organic acids and this is a consequence of increasing DOC or a related phenomenon of the increasing trend in DOC concentrations $(+6.0$ mmol $\mathrm{l}^{-1}$, significant at the 0.05 level) (Evans \& Monteith 2002).

\subsection{Model Calibration (Scottish Highlands)}

The MAGIC model was successfully calibrated to 30 sites in the Scottish Highlands. Simulated present day surface water $\mathrm{ANC}$ and $\mathrm{SO}_{4}{ }^{2-}$ and soil base saturation (BS) compared favourably with observed data (Fig. $5 \mathrm{a}, \mathrm{b}, \mathrm{c})$. The close relationship between the modelled and observed ANC provides a good measure of the accuracy of the calibration since the ANC is not calibrated directly but is calculated from the modelled sum of strong acid anions $\left(\mathrm{Cl}^{-}, \mathrm{SO}_{4}{ }^{2-}\right.$ and $\left.\mathrm{NO}_{3}{ }^{-}\right)$and the sum of base cations $\left(\mathrm{Ca}^{2+}, \mathrm{Mg}^{2+}, \mathrm{Na}^{+}\right.$, and $\left.\mathrm{K}^{+}\right)$. Modelled $\mathrm{SO}_{4}{ }^{2-}$ corresponds exactly to observed $\mathrm{SO}_{4}{ }^{2-}$ since $\mathrm{SO}_{4}{ }^{2-}$ is constrained by the model as result of $\mathrm{SO}_{4}{ }^{2-}$ adsorption so that input equals output.

\subsection{Model Calibration (Lochnagar)}

The decline in modelled $\mathrm{xSO}_{4}$ concentrations at Lochnagar over the period 1988-1997 closely match observed data, subsequently the simulated decline in $\mathrm{xSO}_{4}$ is greater than that observed (Fig. 4c). This indicates that the default values used for $\mathrm{SO}_{4}{ }^{2-}$ adsorption in the soil quantitatively describe the actual retention and release of $\mathrm{SO}_{4}{ }^{2-}$ (Wright et al. 2003). Simulated $\mathrm{NO}_{3}{ }^{-}$concentrations fit observed $\mathrm{NO}_{3}{ }^{-}$data during first 4 years, thereafter observed $\mathrm{NO}_{3}^{-}$concentrations increase and simulated $\mathrm{NO}_{3}^{-}$concentrations gradually decline. In a similar study MAGIC5 (best case $\mathrm{N}$ scenario) and MAGIC7 (worst case $\mathrm{N}$ scenario) were applied to Lochnagar, and the observed increase in surface water $\mathrm{NO}_{3}^{-}$was simulated with MAGIC7 (Jenkins et al. 2001). Jenkins et al. (2001) suggest that soil C:N ratio declined as $\mathrm{N}$ deposition gradually accumulated in the soil. Where the soil $\mathrm{C}: \mathrm{N}$ ratio falls below a threshold value, the extent of deposited $\mathrm{N}$ retained decreased and $\mathrm{N}$ leaching occurs. Post 1993, the higher $\mathrm{NO}_{3}{ }^{-}$concentrations observed at Lochnagar (Figure $4 \mathrm{~b}$ ) may therefore reflect $\mathrm{N}$ leaching, a process that is not represented in the current application. In MAGIC5 however, surface water $\mathrm{NO}_{3}{ }^{-}$concentrations decline in line with $\mathrm{N}$ reductions imposed by the Gothenburg protocol (Fig. 3a), as a result of the change in direct deposition to the loch. The resultant affect of slightly lower simulated concentrations of $\mathrm{NO}_{3}{ }^{-}$and $\mathrm{xSO}_{4}$ on simulated ANC from 1988-2001 is for a small increase compared to observed data. Observed $\mathrm{pH}$ values fluctuate within the range $\mathrm{pH} 4.9$ to 5.8 , but simulated $\mathrm{pH}$ remains within the observed upper and lower limits. During 1993-2001, modelled and observed pH gradually increase. 

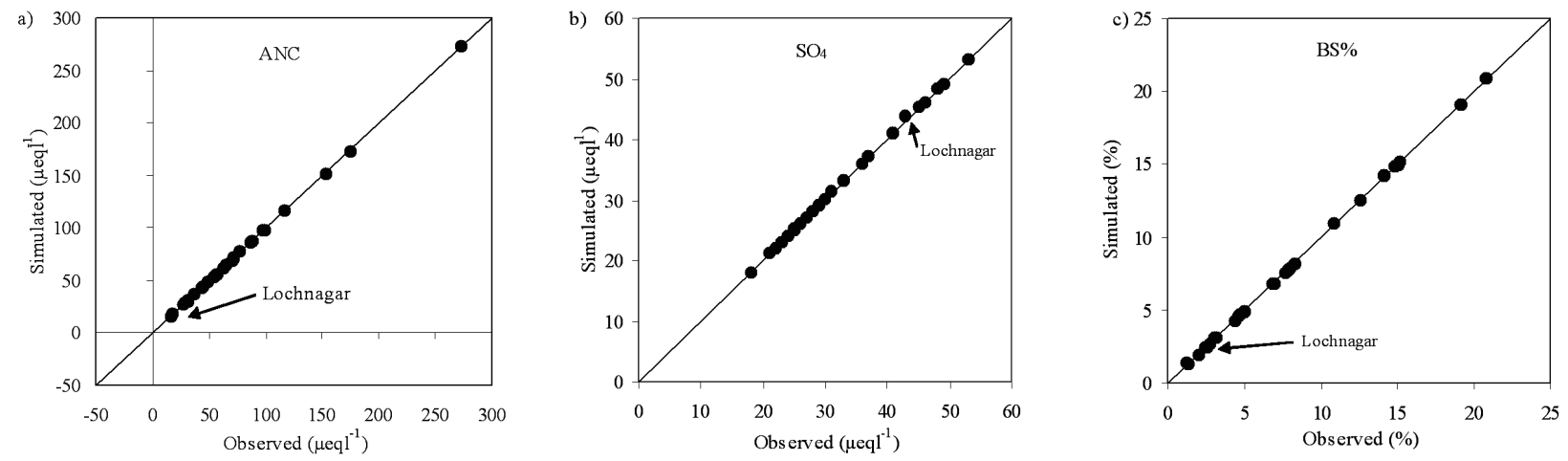

Fig. 5. Observed and modelled present day surface water a) ANC, b) $\mathrm{SO}_{4}{ }^{2-}$ concentrations ( $\mu$ eq $1^{-1}$ ) from the 2000 survey and c) soil base saturation derived from the Scottish Soils Database.

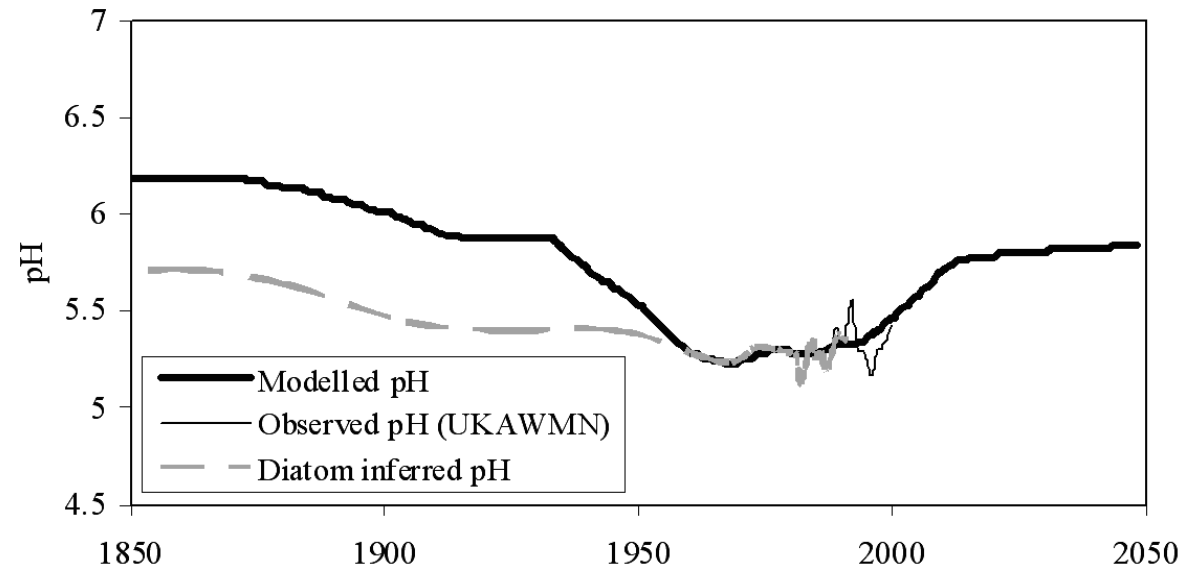

Fig. 6. Comparison of modelled and diatom inferred $\mathrm{pH}$ from a paleolimnological study.

\subsection{Evaluation of historical pH records at Lochnagar}

Comparison of MAGIC reconstructed $\mathrm{pH}$ from preand early-acidification (1860-1950) conditions with independent diatom evidence represent the only means of evaluating both techniques, since no time series of water chemistry exists for such a long period. A detailed assessment of diatom inferred $\mathrm{pH}$ records at Lochnagar and a quantification of the uncertainty associated with these records is provided by Battarbee et al. (1995). Between 1860-1946 diatom inferred $\mathrm{pH}$ ranged from 5.7 (1860) to 5.4 (1946), the modelled $\mathrm{pH}$ during this time (6.2 and 5.6 respectively) indicates that MAGIC is overestimating the pre-acidification $\mathrm{pH}$ of this site (Fig. 6). During 1967 and 1991, however, MAGIC simulated pH shows good agreement with the gradual acidification trend inferred from the diatom reconstruction. A spurious sample taken in 1960 (pH 5.1) was omitted from this record. Although the uncertainties in both approaches are large, close matches between diatom-inferred $\mathrm{pH}$ and MAGIC-simulated $\mathrm{pH}$ during the mid and late twentieth century, and more recent observed $\mathrm{pH}$, increase the confidence in the predictive capacity of the MAGIC model.

\subsection{Response of surface waters to changes in acid deposition}

From the mid $19^{\text {th }}$ century to the 1970 s the median simulated surface water ANC in the Scottish Highlands declined by $22 \mu \mathrm{eq} \mathrm{l}^{-1}$ in response to increased acid deposition (Fig. 7). Following the implementation of international protocols to reduce the emissions of sulphur $(\mathrm{S})$ and nitrogen $(\mathrm{N})$, including the Gothenburg protocol, median ANC at the 30 sites increased from 59 $\mu$ eq $1^{-1}$ in 1975 to $72 \mu$ eq $1^{-1}$ in 2036 . Sites that are most responsive to changes in acid deposition are at the extremes of the acid sensitivity gradient in the Scottish Highlands (Fig. 7). From 1950 to 2005, the minimum ANC trend line represents the regional application of MAGIC at Lochnagar; this allows direct comparison with the site-specific application at Lochnagar (dotted line, Fig. 7). Throughout this period, the site application of MAGIC simulated lower ANC, hence more acid surface water conditions, than the regional application.

Empirical relationships between ANC and fish population status have been developed for brown trout (Salmo trutta L.) and other species in Norway (Lien et al. 1996; Bulger et al. 1993). These studies suggested an 


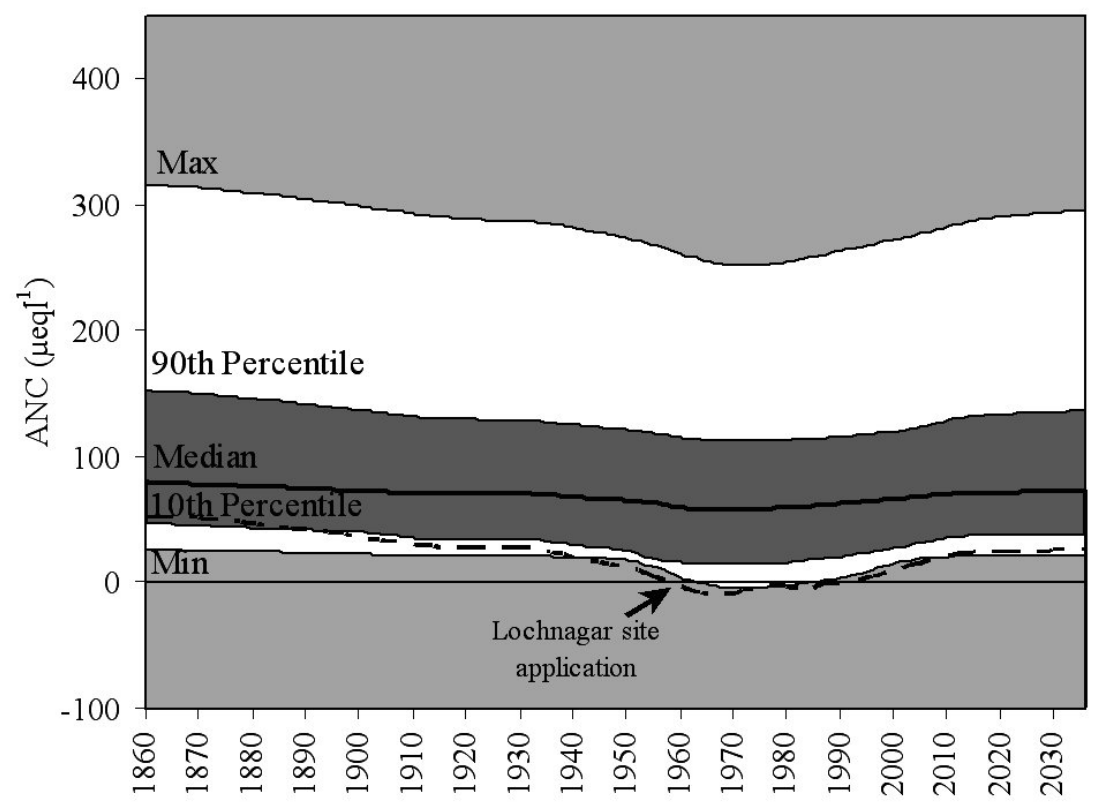

Fig. 7. Change in surface water ANC for 30 sites in the Scottish Highlands and the site application at Lochnagar.

ANC of zero represented a $50 \%$ probability of damage to a brown trout population and an ANC of 20 reflected $95 \%$ protection of the brown trout from damage. For evaluation purposes, an ANC limit of $20 \mu \mathrm{eq} \mathrm{l}^{-1}$ was used to indicate that the sites are capable of achieving the good ecological status as required by the WFD.

The spatial distribution of simulated ANC for 1860 (reference conditions), 1980, 2000 and 2016 are presented (Fig. 8). These maps show how surface waters acidify and recover in response to changes in deposition they also illustrate the inter-regional variability in ANC as a result of site sensitivity across the Scottish Highlands. Prior to the onset of acidification (1860), simulated surface water ANC at all 30 sites in the Scottish Highlands exceeds $20 \mu \mathrm{eq} \mathrm{I}^{-1}$. The MAGIC simulations at this time indicate that chemical conditions in all lochs were sufficient to support trout populations. When S deposition peaked in the $1980 \mathrm{~s}\left(52 \mathrm{meq} \mathrm{m}^{-2} \mathrm{y}^{-1}\right)$, the number of sites with ANC greater than $20 \mu \mathrm{eq} \mathrm{l}^{-1}$ declined to 26 . Sites are generally more sensitive to acidification to the north and east of the Scottish Highlands. At this time, the site with the lowest ANC in the regional MAGIC application is Lochnagar, acidifying to $2 \mu$ eq $\mathrm{l}^{-1}$ (and $-3 \mu \mathrm{eq} \mathrm{l}^{-1}$ for the site application to Lochnagar). Relative to other mountainous regions in Europe such as the Southern Norway and High Tatra Mountains (Slovak-Polish boarder), the extent of surface water acidification in the Scottish Highlands during the 1980s is less due to lower deposition inputs (Jenkins et al. 2003; Wright \& Cosby 2003). By 2000, reduced emission reductions $\left(30\right.$ meq $\left.\mathrm{m}^{-2} \mathrm{y}^{-1}\right)$ result in widespread recovery throughout the Scottish Highlands and, although improvements in ANC are predicted to continue until 2016, a slower rate of recovery is forecast.

\section{DISCUSSION}

In mountainous regions of the UK ecological and chemical recovery have been difficult to authenticate due to a lack of long term monitoring programmes since the 1970 s and early 1980 s. It is clear that sulphur deposition during this period has declined (RGAR 1997), but the majority of hydrochemical and ecological records began in the 1980 s and as a result surface water monitoring data from the 1970 s is extremely limited, particularly in high altitude areas (Evans \& Monteith 2002). In these circumstances, the integration of 'longterm' monitored data within a modelling framework can improve our understanding of the timing, magnitude and extent of change within remote mountain ecosystems.

The availability of representative, good quality data is a principal limiting factor for large-scale modelling initiatives. In this study however, similar soil parameters were derived from both site-specific soil surveys and national databases at Lochnagar (Tab. 3) and, as a consequence, modelled base saturation was comparable throughout the simulation period (1860 to 2036). This result shows that catchment based soil data is not essential for catchment modelling in remote upland areas.

The close resemblance between observed, highresolution data from Lochnagar and modelled trends in surface water chemistry data enhances confidence in the site calibration procedure. Long term modelled $\mathrm{SO}_{4}{ }^{2-}$ concentrations at Lochnagar (both site and regional applications) are similar to observed $\mathrm{SO}_{4}{ }^{2-}$ trends, implying that the regional model performance in the Scottish Highlands is credible. This result suggests that soil processes such as $\mathrm{SO}_{4}{ }^{2-}$ adsorption/desorption and $\mathrm{S}$ reduction/oxidation do not delay the export of $\mathrm{SO}_{4}{ }^{2-}$ to 

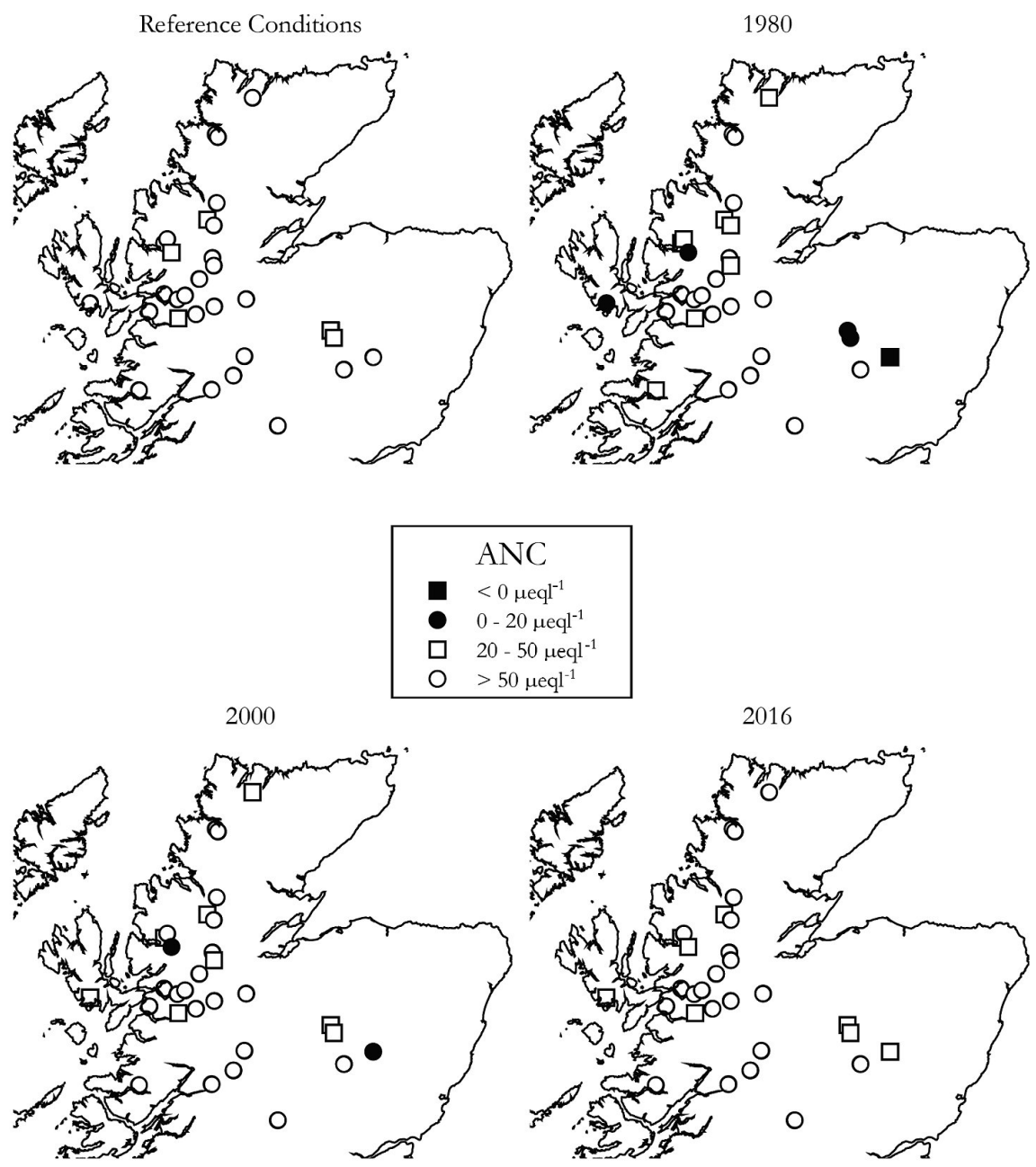

Fig. 8. Biological status inferred from MAGIC modelled surface water ANC. Three ANC classes relate to probability of a viable population of salmonids. Closed square: ANC $<0 \mu \mathrm{eq} \mathrm{l}^{-1}$ unsuitable condition to maintain a viable population; Closed circle: ANC 0$20 \mu \mathrm{eq} \mathrm{l}^{-1}$ marginal condition for the survival of a viable population; Open square: ANC $>20 \mu$ eq $1^{-1}$ good condition to support a healthy population. Four key years are shown: 1860 pre-acidification; 1980 maximum acidification; 2000 present-day; 2016 complete implementation of emission reduction protocols.

surface waters by more than a few years. As with similar catchments in Norway, soils in the Scottish mountains are relatively young, and as a result, the sulphate adsorption capacity is typically low (Wright \& Cosby 2003).

The rate of recovery in simulated ANC from 1990 to 2000 is greater than the observed trends at Lochnagar. Since the trend in surface water $\mathrm{SO}_{4}{ }^{2-}$ is correctly simulated this deviation in ANC reflects the poor $\mathrm{NO}_{3}$ simulation during this period. An alternative explanation might be that base cations are held tightly on the soil exchange complex in these mountain soils in contrast to the MAGIC simulation, and therefore the cation exchange between base cations and aluminium are higher. Verification of these assumptions at other sites in the Scottish Highlands is difficult because of inadequate long-term data at these highly sensitive sites.

The EU Water Framework Directive aims to maintain and improve the quality of aquatic ecosystems in the EU. The results of this modelling study, therefore, have direct significance in relation to achieving that target. The Directive specifies that all surface waters should be managed with the aim of achieving 'good ecological' status by 2016 and this condition may be defined with respect to a reference condition. The reconstructed chemistry (reference condition) and inferred ecology in 1860 indicate that the minimum regional ANC of $26 \mu \mathrm{eq} 1^{-1}$ is sufficient to protect salmonids in surface waters throughout the Scottish Highlands, and therefore, may be considered as achieving the necessary criteria for good ecological status; an ideal benchmark to assess future water acidification conditions in Scotland.

Sulphur deposition peaked in the $1980 \mathrm{~s}\left(52 \mathrm{meq} \mathrm{m}^{-2}\right.$ $\left.\mathrm{y}^{-1}\right)$ and, in response, simulated surface water ANC declined throughout the Scottish Highlands from a regional median of $80 \mu \mathrm{eq} \mathrm{l}^{-1}$ in 1860 to $60 \mu \mathrm{eq} \mathrm{l}^{-1}$ in 1980. While deposition is recognised as the main driver of change in remote areas of Scotland (Helliwell et al. 
2002), site characteristics also influence the rate and extent of change. The most acid surface water conditions were observed in two areas; the Cairngorm/Grampian mountains to the east of the Scottish Highlands where the underlying geology is dominated by granite, and the Northern Highlands where blanket bog and peat predominates. Soils developed from granitic/gneissic parent materials typically have a low base status and therefore a limited capacity to buffer acid inputs. In the 1970-80s, high levels of deposition depleted base cations from soil exchange complexes, which ultimately acidified both soils and surface waters. At Lochnagar, this process is responsible for the small, but highly significant, simulated decline in base saturation from 1860 to 1980 of $0.9 \%$ (site data) and $0.5 \%$ (regional data). To the north of the Scottish Highlands, sites are covered in blanket bog and peat and since organic soils are inherently acid, they are susceptible to acidification when impacted by acid deposition (Hornung et al. 1995). Compared to other mountain ecosystems in Europe, soil base saturation in the Scottish Highlands is very low (Jenkins et al. 2003).

This departure from background conditions in 1980 is predicted to have a marginal impact on brown trout populations in the Scottish Highlands as a whole since the ANC of $87 \%$ of sites is greater than $20 \mu \mathrm{eq} \mathrm{l}^{-1}$. The situation in the Scottish Highlands is therefore encouraging, but the ANC of 4 sites in the region is $<20 \mu \mathrm{eq} \mathrm{l}^{-1}$ and it is unlikely that these conditions will support a viable population brown trout. The success of emission control strategies between 1980 and 2016 resulted in sufficient improvement in surface water quality so that by 2000 the ANC of only 2 sites in the Scottish Highlands was $<20 \mu \mathrm{eq} 1^{-1}$. Predictions to 2016 , the target year for good ecological status (WFD), indicate that under the Gothenburg Protocol, ANC greater than $20 \mu \mathrm{eq}$ $1^{-1}$ will be achieved at all sites.

The nature and extent of future recovery from acidification in the Scottish Highlands is dependent upon the historical trends in deposition, regional ecosystem characteristics, and the role of confounding factors, which may delay the onset of recovery, or the magnitude of response. Climate is widely believed to be undergoing long-term changes in the Scottish mountains (Dunn et al. 2001), and the extent of this change may significantly influence the behaviour of both terrestrial and aquatic ecosystems. If this is the case, climatically driven processes that increase for instance, organic matter turnover and $\mathrm{N}$ mineralisation, may obscure the future acidification status of surface water in mountains regions of Scotland (Rose et al. 2004, this issue).

Sulphur is the key driver of acidification and, more recently, recovery, of surface waters throughout the Scottish Highlands. Nitrogen dynamics are not considered in this analysis, as $\mathrm{N}$ plays a relatively minor role in soil and water acidification, however, with $\mathrm{SO}_{4}{ }^{2-}$ concentrations declining (Fig. 3b), the contribution of ni- trate to the total anion status of surface water will become increasingly important. Little is known about current surface water $\mathrm{NO}_{3}{ }^{-}$trends throughout the Scottish Highlands, but a steady increase in $\mathrm{NO}_{3}{ }^{-}$has been observed at the intensively monitored Lochnagar site during the past 12 years, despite no measured change in inorganic $\mathrm{N}$ deposition (Jenkins et al. 2001). A valid explanation for this trend is difficult since previous attempts to relate surface water $\mathrm{NO}_{3}{ }^{-}$concentrations to soil $\mathrm{C}: \mathrm{N}$ ratios and soil $\mathrm{C}$ pools are likely to be unsuccessful in these montane ecosystems. The thin mineral soils, large areas of bare rock and moraine, typical of high altitude catchments limit the interaction between precipitation and soil and reduces potential terrestrial $\mathrm{N}$ uptake. It is more likely that variability in hydrological pathways, direct deposition to loch surfaces and in-lake processes may have a greater influence on surface water $\mathrm{NO}_{3}{ }^{-}$in mountainous catchments. These factors may confound the recovery of acidification predicted by dynamic models. There is thus a need to consider more explicitly the effects of climate change, increasing organic matter concentration in surface waters, nitrogen deposition and how these influence the processes driving recovery.

\section{ACKNOWLEDGMENTS}

This work was financially supported by two Commission of the European Communities projects EMERGE (EVK1-CT-1999-00032) and RECOVER: 2010 project (EVK1-CT-1999-00018), the Scottish Executive Environment and Rural Affairs Department (SEERAD), and the Department of the Environment, Food and Rural Affairs (Contract No. EPG 1/3/194). We are indebted to the wide community of researchers throughout the UK who have assisted in sample collection, and analysis in particular, Jo Porter, Don Monteith and other colleagues from the ECRC. We also thank Malcolm Coull (Macaulay Institute) for providing GIS support and creating maps. The authors are also grateful to David Fowler, Jane Hall, Sarah Metcalfe and Duncan Whyatt for contributing deposition data and Jordi Catalan (Centre for Advances Spatial Analysis, Blanes, Spain) for supplying geological data for the Scottish Highlands.

\section{REFERENCES}

Battarbee, R.W., J. Mason, I. Renberg \& J.F. Talling. 1990. Palaeolimnology and lake acidification. Phil. Trans. Royal Soc., Series B, 327: 223-445.

Battarbee, R.W., V.J. Jones, R.J. Flower, P.G. Appleby, N.L. Rose \& B. Rippy. 1995. Palaeolimnological for the atmospheric contamination and acidification of high Cairngorm lochs, with special reference to Lochnagar. Bot. J. Scotl., 48: 79-87.

Bulger, A.J., L. Lien, B.J. Cosby \& A. Henriksen. 1993. Brown trout (Salmo trutta) status and chemistry from the Norwegian thousand lake survey: statistical analysis. Can. J. Fish. Aquat. Sci., 50: 575-585.

Chave, P. 2001. The Water Framework Directive: An Introduction. IWA Publishing, London. 
Cosby, B.J., R.C. Ferrier, A. Jenkins \& R.F. Wright. 2001. Modelling the effects of acid deposition: refinements, adjustments and inclusion of nitrogen dynamics in the MAGIC model. Hydrol. Earth Syst. Sci., 5: 499-518.

Cosby, B.J., G.M. Hornberger, J.N. Galloway \& R.F. Wright. 1985a. Modelling the effects of acid deposition: assessment of a lumped parameter model of soil water and streamwater chemistry. Wat. Resour. Res., 21: 51-63.

Cosby, B.J., R.F. Wright, G.M. Hornberger \& J.N. Galloway. 1985b. Modelling the effects of acid deposition: estimation of long term water quality responses in a small forested catchment. Wat. Resour. Res., 21: 1591-1601.

Donner, J.J. 1962. On the post-glacial history of the Grampian Highlands of Scotland. Societas Scientariam Fennica Commentationes Biologicae, 24: 1-29.

Dunn, S.J., S.J. Langan \& R.J.E. Colohan. 2001. The impact of variable snowpack accumulation on a major Scottish water resource. Sci. Tot. Environ., 265: 181-194.

Evans, C., A. Jenkins, R. Helliwell, R. Ferrier \& R. Collins. 2001. Freshwater acidification and recovery in the United Kingdom. Centre for Ecology and Hydrology report. ISBN 190374101 7: 9 pp.

Evans, C.D. \& D.T. Monteith 2002. Natural and anthropogenic changes in the chemistry of six UK mountain lakes, 1988 to 2000. Water Air Soil Pollut., 2: 33-46.

Ferrier, R.C., R.F. Wright, A. Jenkins \& H. Barth. 2003. Predicting recovery of acidified freshwaters in Europe and Canada: An Introduction. Hydrol. Earth Syst. Sci., 7: 431435

Fowler, D., J.N. Cape, I.D Leith, T.W. Chourlton, M.J. Gay \& A. Jones. 1988. The influence of altitude on rainfall deposition at Great Dun Fell. Atmos. Environ., 22: 1355-1362.

Harriman, R., E. Gillespie, D. King, A.W. Watt, A.E.G. Christie, A.A. Cowan \& T. Edwards. 1990. Short-term ionic responses as indicators of hydrochemical processes in the Allt a'Mharcaidh catchment, western Cairngorms, Scotland. J. Hydrol., 116: 267-285.

Henriksen, A, L. Lien, B.O. Rosseland, T.S. Traaen, \& I.S. Sevaldrud. 1989. Lake acidification in Norway - present and predicted fish status. Ambio, 18: 314-321.

Helliwell, R.C., A. Jenkins, R.C. Ferrier \& B.J. Cosby. 2003. Modelling the recovery of surface water chemistry and the ecological implications in the British uplands Hydrol. Earth Syst. Sci., 7: 465-466.

Helliwell, R.C., C.Soulsby, R.C Ferrier, A. Jenkins \& R. Harriman. 1998. Influence of snow on the hydrology and hydrochemistry of the Allt a' Mharcaidh, Cairngorm mountains, Scotland. Sci. Tot. Environ., 217: 59-70.

Helliwell, R.C., R.F. Wright, C.D. Evans, A. Jenkins \& R.C. Ferrier 2002. A comparison of loch chemistry from 1955 and 1999 in the Cairngorms, N.E. Scotland. Water Air Soil Pollut., 2: 47-59.

Hornung, H., K. R. Bull, M. Cresser, J. Hall, S. J. Langan, P. Loveland \& C. Smith. 1995. An empirical map of critical loads of acidity for soils in Great Britain. Environ Pollut., 90: 301-310.

Huntley, B. 1981. The past and present vegetation of the Caenlochan National Nature Reserve, Scotland II. Palaeological investigations. New Phytol., 87: 189-222.

Jenkins, A., L. Camarero, B.J. Cosby, R. Ferrier, M. Forsius, R.C. Helliwell, J. Kopacek, V. Majer, F. Moldan, M. Posch, M. Rogora, W. Schöpp \& R.F. Wright. 2003. A modelling assessment of acidification and recovery of European surface waters. Hydrol. Earth Syst. Sci., 7: 447455 .

Jenkins, A., R.C. Ferrier \& R.C. Helliwell. 2001. Modelling nitrogen dynamics at Lochnagar, N.E. Scotland. Hydrol. Earth Syst. Sci., 5: 519-527.

Jenkins, A., R.C. Helliwell, P.J. Swingewood, C. Sefton, M. Renshaw \& R.C. Ferrier. 1998. Will reduced sulphur emissions under the Second Sulphur Protocol lead to recovery of acid sensitive sites in the UK? Environ. Pollut., 99: 309-318.

Jenkins, A., P.G. Whitehead, B.J. Cosby \& H.J. Birks. 1990. Modelling long term acidification: a comparison with diatom reconstructions and the implication for reversibility. Phil. Trans. Royal Soc. London, B327: 435-440.

Johnson, R.C. \& D.B. Thompson, 2002. Hydrology and the natural heritage of the Scottish Mountains. Sci. Tot. Environ., 294: 161-168.

Jones, V.J., R. Flower, P.J. Appleby, J. Natkanski, N. Richardson, B. Rippey, A.C. Stevenson. \& R.W. Battarbee. 1993. Palaeolimnological evidence for the acidification and atmospheric contamination of lochs in the Cairngorm and Lochnagar areas of Scotland. J. Ecol., 81: 3-24.

Juggins, S., R. Flower \& R. Battarbee. 1996. Palaeolimnological evidence for recent chemical and biological changes in UK Acid Waters Monitoring Network sites. Freshwater Biol., 36: 203-219.

Langan, S.J. \& C. Soulsby. 2001. The environmental context for water quality variation in Scotland. Sci. Tot. Environ., 265: 7-14.

Lien, L., G.G. Raddum, A. Fjellheim \& A. Henriksen. 1996. A critical limit for acid neutralizing capacity in Norwegian surface waters, based on new analyses of fish and invertebrate responses. Sci. Tot. Environ., 177: 173-193.

Monteith, D.T. \& C.D. Evans. 1998. United Kingdom Acid Waters Monitoring Network 10 Year Report Analysis and Interpretation of Results, April 1988 - March 1998. ENSIS Publishing, ISBN 1871275261.

Monteith, D.T. \& C.D. Evans (Eds). 2000. The UK Acid Waters Monitoring Network: 10-Year Report. Analysis and Interpretation of Results, April 1988-March 1998. ENSIS Publishing, London.

Mylona, S. 1996. Sulphur dioxide emissions in Europe 18801991 and their effect on sulphur concentrations and depositions. Tellus, 48B: 662-689.

NEGTAP. 2001. Transboundary air pollution: acidification, eutrophication and ground-level ozone in the UK. DEFRA contract (EPG 1/3/153), ISBN 1870393.

Pears, N.V. 1968. Post-glacial tree lines of the Cairngorm Mountains, Scotland. Transactions of the Botanical Society of Edinburgh, 40: 361-394

Posch, M., W. Schöpp, M. Johanson \& S. Mylona. 2002. 150 Years of Sulphur and Nitrogen Deposition in Europe (1880-2030). IIASA, Laxenburg, Austria.

Raddum, G.G. \& B.L. Skjelkvale. 2001. Critical limit of acidifying compounds to invertebrates in different regions of Europe. Water Air Soil Pollut., 130: 825-830.

RGAR, 1997. Acid Deposition in the United Kingdom 199294. Fourth Report of the Review Group on Acid Rain. AEA Technology, Culham, UK.

Rose, N., D. Monteith, H. Kettle, R. Thompson, H. Yang \& D. Muir. 2004. A consideration of potential confounding factors limiting chemical and biological recovery at Lochnagar, a remote mountain loch in Scotland. J. Limnol., 63(1): 63-76.

Simpson, D., K. Olendrzynski, A. Semb, E. Støren, E \& S. Unger. 1997. Photochemical oxidant modelling in Europe: multi-annual modelling and source-receptor relationships. EMEP/MSC-W Report 3/97, Norwegian Meteorological Institute, Oslo, Norway: 75 pp.

Wright, R.F. \& B.J. Cosby, B.J. 2003. Future recovery of acidified lakes in southern Norway predicted by the MAGIC model. Hydrol. Earth Syst. Sci., 7: 467-483.

UN-ECE. 1999. The 1999 Protocol to Abate Acidification, Eutrophication and Ground-level Ozone. Document ECE/EB.AIR/72. United Nations Economic Commission for Europe, New York and Geneva: 219 pp. 